DOI: https://doi.org/10.15688/lc.jvolsu.2017.4.9

UDC 342.4

LBC 67.400

\title{
REVISITING THE HIERARCHY OF CONSTITUTIONAL VALUES
}

\author{
Svetlana E. Nesmeyanova \\ Ural State Law University, Ekaterinburg, Russian Federation
}

\begin{abstract}
Introduction: the constitution of any state enshrines the recognized as such values needed for the progressive development of the society, but in the theory of constitutional law there are not yet developed common approaches to defining their hierarchies, wherefore, the author of the work sets the aim to identify the issues and possible classification of constitutional values and their hierarchy. Methods: a methodological framework for this study is a set of scientific methods, among which the main place is occupied by the methods of structure, systematicity, analysis and the comparative law method. Results: grounded in the work the author's viewpoint is based on the provisions of the constitution of the Russian Federation. On the basis of the legal analysis of constitutional values the author offers to not only classify them, but also to recognize universal benefits provided by the international community, and the values established in the decisions of the bodies of constitutional justice as the constitutional values. Conclusions: the study concluded about the need for developing the theory of constitutional axiology, developing the concept of constitutional values, determining their place in the system of values in general and the role of Constitutional Court of the Russian Federation to ensure the balance of values.

Key words: constitutional values, system of values, criteria of classification of constitutional values, hierarchy of values, balance of constitutional values, the role of the Constitutional Court of the Russian Federation in the development of constitutional values.
\end{abstract}

УДК 342.4

ББК 67.400

\section{К ВОПРОСУ ОБ ИЕРАРХИИ КОНСТИТУЦИОННЫХ ЦЕННОСТЕЙ}

\section{Светлана Эдуардовна Несмеянова}

Уральский государственный юридический университет, г. Екатеринбург, Российская Федерация

Введение: конституция любого государства закрепляет признаваемые таковыми ценности, необходимые для прогрессивного развития общества, но в теории конституционного права до сих пор не выработаны общие подходы к определению их иерархии, в связи с чем автором в работе поставлена цель обозначить соответствующую проблематику и определить возможную классификацию конституционных ценностей и их иерархию. Методы: методологическую основу данного исследования составляет совокупность методов научного познания, среди которых основное место занимают методы структурности, системности, анализа и сравнительно-правовой метод. Результаты: обоснованная в работе авторская позиция опирается на положения Конституции Российской Федерации. На основании правового анализа конституционных ценностей n предлагается провести не только классификацию таковых, но и признать конституционными ценностями ᄅे выработанные международным сообществом универсальные блага, а также ценности, установленные в : решениях органов конституционной юстиции. Выводы: в результате исследования сделан вывод о необход димости развития теории конституционной аксиологии и выработки понятия конституционных ценностей, определения их места в системе ценностей вообще и роли Конституционного суда РФ в обеспечении баланса ценностей.

Ключевые слова: конституционные ценности, система ценностей, критерии классификации конституционных ценностей, иерархия ценностей, обеспечение баланса конституционных ценностей, роль Конституционного суда РФ в развитии конституционных ценностей. 
Вопросы определения конституционных ценностей, их классификация, значение в развитии конституционного права и всей российской правовой системы ставились давно. При этом следует признать, что теория конституционной аксиологии, как наука, изучающая совокупность конституционных ценностей и взаимосвязей между ними, не получила своего должного развития до сегодняшнего дня [1;2].

Не до конца исследованным является само понятие «конституционные ценности». По-видимому, к ним относятся характеристики, блага, которые закреплены в конституции государства в отношении самых разных явлений, воспринимаемые как самые значимые, важные и обязательные. Но нам представляется, что к конституционным ценностям мы можем отнести и те, которые установлены международными общепризнанными нормами и принципами, и признаются конкретным государством. При этом данные ценности (признанные на международном уровне) не должны в обязательном порядке дублироваться в тексте конституции государства, а потому ограничение конституционных ценностей только закрепленными в конституции представляется не вполне верным. Более того, конституционной ценностью является и сама конституция страны, если она признается в качестве легитимного акта и способствует развитию государства и общества (то есть сама закрепляет определенныеценности). Так, например, Конституция РФ, обладая такими свойствами, как высшая юридическая сила, особый порядок принятия и изменения ее текста, особая правовая охрана, безусловно, сама является ценностью, закрепляя основныепринципы организации государства и общества, определяя приоритет человека, его прав и свобод.

Кроме этого, конституционными ценностями следует признать некоторые положения, получившие свое признание через решения органов, осуществляющих правовую охрану конституции, в том числе ее толкование. Таким образом, под конституционными ценностями можно понимать прямо предусмотренные конституцией государства, признаваемые или вытекающие из ее сути наиболее значимые характеристики разных явлений, способствующие развитию личности, общества и государства.
Тем не менее большинство конституционных ценностей все же закреплено конституционными нормами. Поэтому, говоря именно о конституционных ценностях, мы должны соотносить их с принципами обязательности и верховенства, которые имеют прямое отношение к конституционным нормам.

Относительно классификации конституционных ценностей вопрос остается открытым, поскольку конституционный текст совершенствуется, дополняется, а следовательно, меняется и перечень конституционных ценностей, которые подлежат классификации. Более того, необходимо признать, что перечень конституционных ценностей соотносится с существующими в конкретный промежуток времени в конкретном государстве политическими, экономическими, социальными возможностями и потребностями. Поэтому конституционные ценности могут оцениваться и соотноситься между собой только в рамках действующего текста конституции. Более того, приоритет одних конституционных ценностей над другими может определяться применительно к конкретной ситуации, когда, например, речь идет об ограничениях, предусмотренных федеральным законом в целях охраны конституционно значимых ценностей (в соответствии с Конституцией РФ), когда есть возможность наступления или реальной угрозы причинения вреда конституционно охраняемым ценностям, когда определенные события ведут к ослаблению их защиты.

Говоря о многообразии конституционных ценностей, следует выделять ценности по видовому признаку. Так, в первую очередь следует выделить такую конституционную ценность, как человек, его права и свободы, что прямо определено Конституцией РФ (ст. 2) и детализируется в самостоятельной главе. Кроме этого возможно выделение ценностей, определяющих основы конституционного строя России, учитывая приоритет норм главы 1 Конституции (ст. 16). Следует подумать о тех ценностях, которые перечислены в преамбуле Конституции РФ, но при этом не повторяются в нормативных положениях собственно самого конституционного текста (например, утверждая гражданский мир и согласие, стремясь обеспечить благополучие и процветание России и др.). В иных главах Кон- 
ституции ранее названные ценности детализируются, раскрываются, определяются обеспечительные меры, посредством применения которых они могут быть реализованы. Однако представляется, что и в последующих положениях Конституции мы можем обнаружить конституционные ценности. В частности, это касается главы 7, определяющей параметры функционирования судебной власти, и, возможно, главы 8, устанавливающей границы осуществления местного самоуправления.

Ценности могут быть под защитой конституции или международных договоров. Но это не предполагает, что такие ценности будут иметь однозначное преимущество перед другими конституционно значимыми ценностями.

При этом необходимо признать наличие конституционных ценностей, не подвергаемых сомнению, например, это права и свободы человека, которые являются конституционной ценностью любого современного государства. Однако возможно выделение тех ценностей, которые признаются отдельными странами исходя из их государственного устройства, политического режима, формы правления, отношения к религии или других характеристик. Поэтому сложно для разных государств предложить универсальные конституционные ценности в разных сферах. Тем не менее в условиях международной глобализации, развития механизмов защиты, в частности, прав человека, международное сообщество стремится к оптимизации ценностей. Поэтому принято говорить об универсальных ценностях. Однако в современных условиях при появлении все большего количества различных угроз очень сложно поддерживать эти принципы, развивать их, определять значимость одних или других ценностей в различных правоотношениях.

Дополнительными критериями классификации конституционных ценностей могут быть интересы субъектов (публичные и частные). Следует признать, что в любых правоотношениях субъекты реализуют и защищают свои интересы, основываясь на определенных ценностях. Исходя из этого, субъектами, имеющими определенные ценностные интересы, выступают человек, объединения (включая партии, профсоюзы, религиозные конфессии и др.), органы государственной власти и местного самоуправления. В тексте любой кон- ституции возможно выделение ценностей общества (гражданского общества) и государства (правового государства).

В конституционных текстах, учитывая названные ценности, можно выделить ценности по уровню их обобщенности - конкретные и абстрактные; по объекту усвоения - материальные и процессуальные, морально духовные; по субъекту - личные, коллективные, общечеловеческие и др.

Признавая наличие многообразия конституционных ценностей, применение различных критериев для определения их иерархии, необходимо признать, что любая классификация ценностей является достаточно условной, учитывая возможность определения новых ценностей. Тем не менее вполне можно говорить о системе ценностей, в том числе конституционных. При наличии системы важным является вопрос сохранения баланса ценностей, локализации противоречий при оценке тех или других ценностей и определении верховенства одних ценностей над другими. Так, например, в Конституции Российской Федерации в ст. 2 провозглашается приоритет именно человека, его прав и свобод, что признается высшей ценностью в государстве. При этом в ст. 16 Конституции установлено верховенство норм, определяющих основы конституционного строя. Каким образом определить иерархию названных ценностей, например, в рамках основ конституционного строя? Особенно сложно это сделать, учитывая, что упоминаемые ценности закрепляются в нормах Конституции, которые сами по себе обладают верховенством (ст. 15).

Не менее интересным является вопрос о возможной иерархии ценностей внутри конкретной группы. Так, например, Конституция РФ, провозглашая человека, его права и свободы высшей ценностью во взаимоотношениях человека с государством, закрепляет за ценностями отдельные права, которые как объект наиболее интересны отдельной личности как субъекту конкретных правоотношений. Какие права наиболее приоритетны как ценности? Принимая во внимание практику Европейского суда по правам человека и решения Конституционного суда РФ, необходимо констатировать, что суды не определяют верховенство конкретных ценностей при раз- 


\section{ТЕОРИЯ И ПРАКТИКА ГОСУДАРСТВЕННО-ПРАВОВОГО РАЗВИТИЯ}

решении спора (при наличии конкуренции ценностей). Они лишь определяют приоритет конкретной ценности в конкретных правоотношениях. Не менее значимой является проблема возможного ограничения прав и свобод на основании ч. 3 ст. 55 Конституции РФ (в интересах защиты основ конституционного строя, нравственности, здоровья, прав и законных интересов других лиц, обеспечения обороны страны и безопасности государства). Представляется, что в данном случае речь идет не об ограничении собственно конституционной ценности, а лишь об ограничении конкретного права в определенных обстоятельствах при выполнении жестких ограничений).

Признавая наличие целой системы ценностей, в том числе конституционных, необходимо внимательно отнестись к вопросу их соотношения, внутренней иерархии, взаимодействия, определения приоритета одних ценностей над другими. Особенно важным это становится тогда, когда в рамках одних правоотношений есть необходимость применения разных конституционных ценностей. Участники подобных правоотношений, каждый в своих интересах, заинтересованы использовать наиболее подходящие на их взгляд ценности. При этом речь не идет о злоупотреблении правом, а именно о возможности правового применения ценностей. При возникновении подобной ситуации применительно к конституционным ценностям следует признать особую роль органа конституционной юстиции в вопросах определения баланса ценностей применительно к конкретным правоотношениям. Именно Конституционный суд РФ при реализации сво- их полномочий обеспечивает баланс различных ценностей, их осмысление и значение в прогрессивном развитии государства и общества, теории и практики конституционализма.

\section{СПИСОК ЛИТЕРАТУРЫ}

1. Боков, Ю. А. Принципы аксиологического подхода и проблема совершенствования конституционного законодательства / Ю. А. Боков, Е. Г. Васильева // Вестник Волгоградского государственного университета. Серия 5, Юриспруденция. -2014. № 2 (23). - С. 69-74.

2. Гаврилова, Ю. А. Смысловые доминанты конституционализма в России / Ю. А. Гаврилова // Вестник Волгоградского государственного университета. Серия 5, Юриспруденция. - 2014. № 1 (22). - C. 51-55.

\section{REFERENCES}

1. Bokov Yu.A., Vasilyeva E.G. Printsipy aksiologicheskogo podkhoda i problema sovershenstvovaniya konstitutsionnogo zakonodatelstva [The Principles of Axiological Approach and the Problem of Improving the Constitutional Legislation]. Vestnik Volgogradskogo gosudarstvennogo univesiteta. Seriya 5, Yurisprudentsiya [Science Journal of Volgograd State University. Jurisprudence], 2014, no. 2(23), pp. 69-74.

2. Gavrilova Yu.A. Smyslovye dominanty konstitutsionalizma v Rossii [Semantic Dominants of Constitutionalism in Russia]. Vestnik Volgogradskogo gosudarstvennogo univesiteta. Seriya 5, Yurisprudentsiya [Science Journal of Volgograd State University. Jurisprudence], 2014, no. 1 (22), pp. 51-55.

\section{Information about the Author}

Svetlana E. Nesmeyanova, Doctor of Juridical Sciences, Professor of Department of Constitutional Law, Director of the Institute of State and International Law, Ural State Law University, Komsomolskaya St., 21, 620131 Ekaterinburg, Russian Federation, nesmeyanova@yandex.ru.

\section{Информация об авторе}

Светлана Эдуардовна Несмеянова, доктор юридических наук, профессор кафедры конституционного права, директор Института государственного и международного права, Уральский государственный юридический университет, ул. Комсомольская, 21, 620131 г. Екатеринбург, Российская Федерация, nesmeyanova@yandex.ru. 